\title{
Board Characteristics, Audit Committee and Ownership Structure Influence on Firm Performance of Manufacturing Firms in India
}

\author{
Palaniappan Gurusamy \\ Department of Management Studies, Vinayaka Missions Kirupananda Variyar Engineering College, Salem, Tamil Nadu, India
}

\section{Email address:}

palani.sunn@gmail.com,palaniappan@vmkvec.edu.in

\section{To cite this article:}

Palaniappan Gurusamy. Board Characteristics, Audit Committee and Ownership Structure Influence on Firm Performance of Manufacturing Firms in India. International Journal of Business and Economics Research. Vol. 6, No. 4, 2017, pp. 73-87. doi: 10.11648/j.ijber.20170604.16

Received: April 29, 2017; Accepted: June 15, 2017; Published: July 24, 2017

\begin{abstract}
The study investigates the relationship and impact of corporate governance measures such as board characteristics, audit committee and Ownership Structure on the financial performance of the selected manufacturing firms listed in Bombay Stock Exchange (BSE). The study empirical in nature and applies panel data regression analysis to a sample of 357 manufacturing firms listed in BSE during the period 2006-2015. The study found that board size is positively and significantly linked to both the financial performance measures, i.e. Return on assets (ROA) and Return on Equity (ROE) but the negative and insignificant impact in case of Tobin's Q. Audit committee independence is significant and negatively affected by ROE. The same promoters' shareholding is negatively and significantly related to all the financial measures and there is an insignificant negative relationship between institutional shareholding and both financial performance measures (Tobin's Q and ROA). The study implies that to improve the performance and accordingly the value of firms, the percentage of promoters' ownership should be decreased as it has positive linkages with the financial performance. The board members have potential knowledge and expertise in the field should be increased as it has aligned with accounting based financial performance. Further, it will help the investors to pay special attention to the corporate governance, audit committee and type of ownership of firms while making the investments.
\end{abstract}

Keywords: Corporate Governance, Audit Committee, Ownership Structure, Financial Performance, Panel Data, Manufacturing Firms

\section{Introduction}

Corporate governance $(\mathrm{CG})$ in particular board related characteristics can play a significant role in enhancing firm's performance and at the firm's dedication and adoption of ethical practices within an entire organizational structure. When there is a separation of ownership between the proprietors-the shareholders (principals) and the managers (agents), the shareholders are unable to engage in management and it is the duty of the instrument panel to represent the shareholder's interests. The plank of directors of companies owns the task to ensure that managers of corporations use the assets to maximize shareholders' value. In summation, the board of directors is also anticipated to facilitate and monitor the effectiveness of management to insure legal compliance and to prevent unlawful and immoral conduct. The prime aim of corporate governors is to derive competitive advantage in a free market knowledge economy [1]. This competitive edge is possible if corporate governance measures enhances value through exploiting all available resources. A good corporate governance practices ensure better decision making, operational efficiency, and reduction in wastes. It further balances the interests of all stakeholders, including executives and non-executive [2]. Shareholders can believe that companies with good CG practices make sure that free cash flow should be returned to shareholders as dividend rather than being expropriated by the insiders [3].

Big corporate scandals in the USA during the years 2000 and 2001 (Enron, WorldCom and Tyco, etc.) and the rest of the world left deep scars in the corporate world. These scandals pushed regulatory authorities to bring laws against complains about corruption, frauds, deception and insider 
trading such as Sarbanes-Oxley Act, 2002. It was proved that the traditional governance structure could not stop the expropriation of insiders and was a source of inefficiency. Due to these scandals faiths of the investors on capital market was shaken. As a result, regulatory authorities around the world made it compulsory for corporate sector to comply with the code of best CG practices to promote the transparency, accountability and fairness for all stakeholders.

India, the renewed focus on the functioning of corporate boards along with a debate on the rights and responsibilities of board members followed the disclosure failures at Satyam Computer Services by the company's founder-chairman's own admission, had continued for seven long years [4]. To make these structurally and operationally more effective in ameliorating agency problems between shareholders and owners/managers. This has included a whole gamut of reforms evolving over time to deal with the constitution and functioning of corporate boards, the most important of which are regulations aimed at ensuring board independence from internal management and improving the quality of board governance. The universally accepted principle is that the board of directors acts as fiduciaries of shareholders' and other stakeholders' interest. Because previous studies show that poorly governed firms have lower operating performance while better governed firms demonstrate higher financial performance and market valuation [2] [5]. Firms with good CG practices not only grant more cash dividend but also more rights to its shareholders. Thus, the board characteristics and their activity have significant effects on the firm performance. Hence, this study aims to examine the influence of good corporate governance (CG) specifically board characteristics, audit committee and ownership structure on firms' performance.

\section{Review of Literature}

In the early literature, the relationship between $\mathrm{CG}$ and corporate performance has been widely studied but reached no consensus. There is a widely held view that good corporate governance practices are associated with better firm performance.

\subsection{Board Characteristics and Firm Performance}

Board Size: Several studies have examined the relationships between board size, board effectiveness, and company performance. The few studies arguably suggested that smaller boards (of seven or eight directors) were more effective, while [6] [7] extended these numbers to a maximum of 10 directors. There is no legislative mandate in India on board size except for certain minimum requirements two in the case of private limited companies, and three in the case of public limited companies. The Companies Bill, 2013 has proposed a maximum of 15 directors unless a higher number is approved by the members through a special resolution. In India, empirical data from three studies found the median size of boards ranging from 8 to 11 [8] [9] [10] investigated the board size, with corporate financial performance using data of 504 corporations belonging to 18 industries and found that the size of the board played an important role in influencing the financial performance of corporations. The same results were predicted by [11] [12] [13] [14]. Even according to resource dependency theory larger boards are preferred due to a wider pool of expertise and see in the outside world. On the other side, it sees larger boards bring coordination problems of the boards are preferable due to close interactions and debates. The board size exerts negative influence on corporate performance, irrespective of whether performance-based or market-based measure is considered [15]. And, also established that the results were consistent with the theory that when boards get to be too big, agency problems increase [16]. The larger boards lead to a slowing of decision-making, a tendency toward passivity that leads to adverse impact on performance [17]. Similarly, found a negative correlation between board size and firm performance [18] but [19] [20] concluded that Board size does not have any relation to firm performance.

H01: There is no significant relationship exists between board size and financial performance of Indian manufacturing firms.

CEO Duality: The Indian approach to the duality issue is grounded upon the British situation. The SEBI (Kumar Mangalam Birla) Report on corporate governance recognized the differing roles of the two positions and expressed itself in favor of separating them, but stopped short of mandating this as a requirement. Thus, the relevance of separation of these positions into an independent non-executive board chair and an executive managing director is indeed very strong [21]. CEO duality is the long debated issue in board studies. Duality refers to situations in which the Chief Executive Officer (CEO) position is combined with the Board Chair position. It is widely assumed that separating the role of chairman of chief executive would secure a board sufficient power to challenge CEO dominance. Some studies stated that when the CEO duality arisen and the company performance decreases because the independent directors were less able to exert their supervisory capacity under CEO duality whereas similar to negative association between ROE and CEO duality [22]. The CEO's powers have a damaging effect on functioning was not sustained [14] establish that only on the other side considerable benefits of CEO duality also suggested by some researchers like [12] found CEO duality was positively associated with solid performance.

H02: There is no significant relationship exists between CEO Duality and financial performance of Indian manufacturing firms.

Board Independence: Board independence is regarded an important tool for increasing the firm performance. Independent directors have the incentive to elevate the interests of shareholders and be effective mentors, in parliamentary procedure to protect their reputational capital and being sued by shareholders [23] [24]. The need to have independent boards arises from the agency-theoretic premise that if boards exist to monitor shirking or self-dealing by inside management, then outside directors in general, and 
independent directors in particular, should be more effective monitors than are insiders whose interests may be at odds with outside shareholders. In alternative view, the effectiveness of independent directors in mitigating managerial opportunism and serving shareholder interests [4]. The members' independence has a positive impact on company performance [25] proved that, while some studies find the beneficial effects of more independent boards on firm performance [26]. The firms with a high percentage of independent directors may perform worse [27] [28]. While the move towards constituting independent directors has gained increasing momentum over the years, and companies are embracing board independence relatively easily as has been the case in India, surprisingly no conclusive empirical evidence exist to suggest that board independence matters in firm performance. The relation of board structure through the appointments of outside directors on a sample of 335 firms [29]. They found a positive relation between the ratios of outside directors with firm's return-on-assets. The proportion of outside directors has a significant correlation with the market-based measures of performance, but no significant correlation with the accounting-based measures [11]. Some studies evidenced has no significant relationship between independent board and value maximization. The company's performance does not depend on how much the directors received their compensation, but more on the number of directors at a board or the proportion of executive and nonexecutive directors on a board [30]. The board composition has a negative relationship with Tobin's q implying that when there were more external board members, the performance of the firm tends to be worse [31].

H03: There is no significant relationship exists between Board Independence and financial performance of Indian manufacturing firms.

Board Meeting: Board Meetings are used as a measure of intensity of board activity. The number of board meetings per year represents the depth of board involvement in monitoring. There is no relationship between the proportion of independent non-executive directors, board size and the frequencies of meetings conducted and corporate performance [31]. A brief perusal of the above studies suggests that voluminous research exists on this topic in both developed and developing economies, but the results are not conclusive. Moreover, in the same country different studies shave produced conflicting results. So there is a need for a stronger test to discern whether the board variables have any effect on firm performance. The study explores this relationship empirically, and uses board meeting, found that contradictory results of firms' performance parameters. This results with consistent of previous studies [32] [33] [34] [35].

H04: There is no significant relationship exists between frequency of board meeting and financial performance of Indian manufacturing firms.

\subsection{Audit Committee and Firm Performance}

The number of members of the Audit Committee should not be too high in order to avoid dispersion of responsibility
[36]. Considering audit committee meetings as a proxy for internal control systems which is a positive relationship between firm size and audit meetings [37] [38] [39] [40]. The audit committees' total independence, the number of meetings and the attendance have a positive relationship with firm performance measured by Tobin's Q [41]. Tobin's Q, proxy for firm performance and firm values, has an impact on the frequency of board meetings [42] while few study [43] argues that there is an association between audit committee members' independence and the drop in fraud cases and that the dimension of the audit committee and the professional expertise of its members do not influence the reduction of cases of distorted income reporting. The proportion of members which are financial and accounting professionals has the highest positive and significant impact on both the evolution of return on assets and return on equity [44]. The relationship between audit committee index and firm values is found to be positive and significant in the Indian context [41].

H05: The size of the audit committee does not influence on firm performance.

H06: The audit committee independence has a positive influence on firm performance.

\subsection{Ownership Structure and Firm Performance}

Evidence that a higher ownership concentration improves firm performance as large shareholders have both the incentives as well as resources to monitor managerial decisions closely. They also indicate that ownership concentration helps the takeover market to operate effectively [2]. The previous studies found that positive correlation between ownership concentration and profitability, whereas no evidence of a relationship between ownership concentration and profitability and accounting returns.

Promoter shareholding: Under the control of promoter ownership, family members, relatives, and friends from the board of directors while, a study [3] demonstrated that concentrated ownership has become the most vulgar kind of ownership in most of the nations in the creation. Indeed, family control through promoter ownership is the most common in India. Promoter ownership has a major impact on corporations in terms of controlling leverage because promoters have considerable ability to arrive at strategic decisions. Still, too much power in the hands of promoters and their associates may become detrimental because it enables them to follow their own interests rather than corporate interests which leads to an agency problem. The power to prosecute their own personal interests comes from voting rights and control over management, which enables promoters and their fellows to pursue their own interests by developing corporate policies that may cause a negative impact on the firm. [45] noted a negative correlation between ownership concentration and profitability on a panel of Italian firm. The few studies has been found that non-linear relationship between the result of insider ownership on corporate value in India

H07: The promoter shareholding has a positive influence 
on firm performance.

Institutional Shareholding: Another, important aspect of measures [46] provided evidence in favour of the significant effect of managerial and institutional shareholding on performance. The results of [47] were inconclusive and pointed out the importance of the type of owner: control by a financial company improves performance whereas control by a non-financial company tends to be negatively correlated with productivity growth while, [48] found a positive relation between ownership and performance. The study indicated that institutional ownership exerted a direct and significant influence on corporate governance in areas such as board composition, CEO duality, leadership diversity, and ownership concentration [49].

H08: The institutional shareholding has positive influence on firm performance.

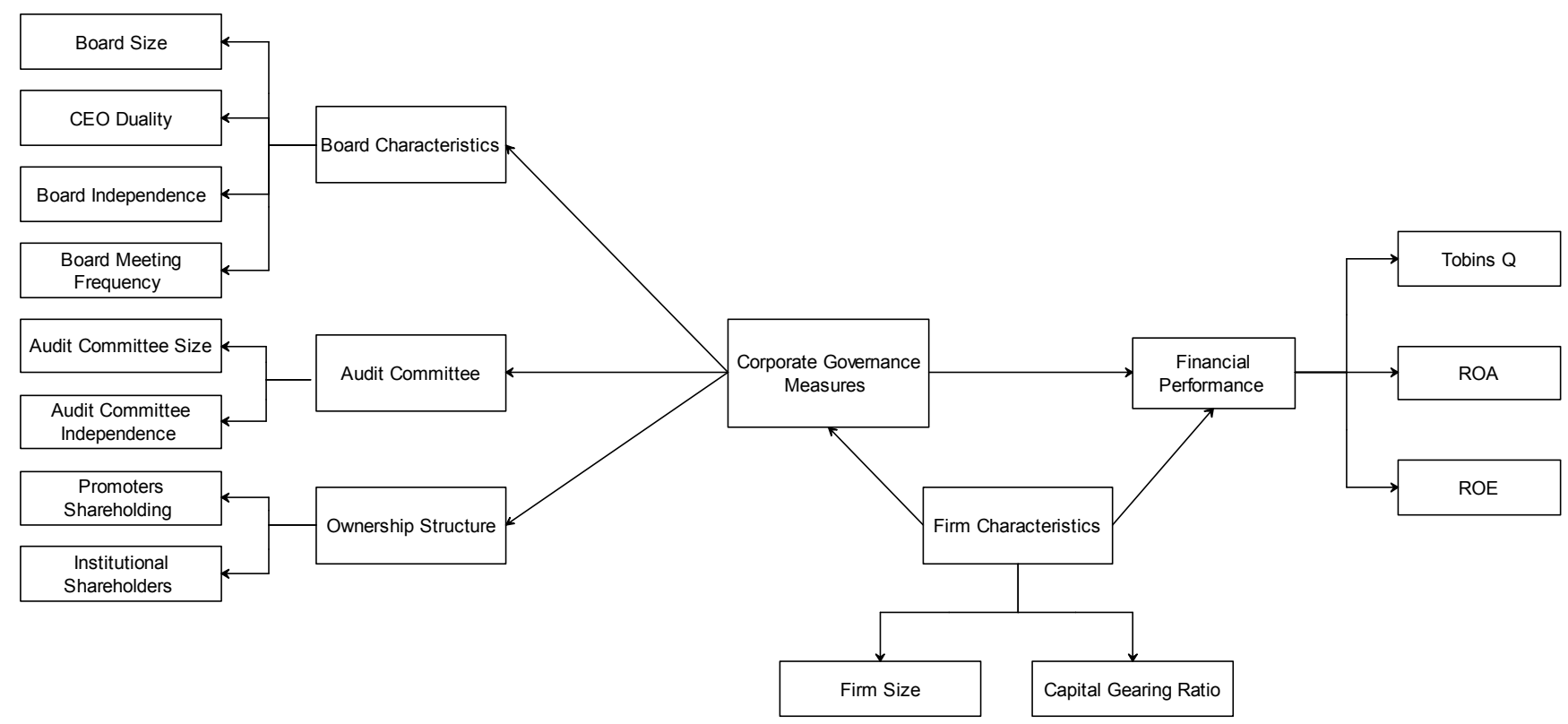

Figure 1. Proposed research model framework.

\section{Research Methodology}

\subsection{Sample and Data Source}

To investigate the relationship between board characteristics, audit committee and ownership structure and firm performance an initial sample of BSE listed Indian manufacturing firms during the year 2006-2015 has been taken from CMIE-PROWESS database. Final sample includes 357 companies after excluding financial and public sector units due to different regulatory environments. The companies with different financial years, the outliers and the companies for which the data is not available are also excluded from the sample. Secondary sources have been used for this study. The data regarding board variables have been taken from the corporate governance reports filed by sampling companies with BSE, Companies web sites and
CMIE-PROWESS database. Financial data regarding performance variables and control variables have been taken from prowess database.

\subsection{Empirical Model and Variable Definition}

Panel regression analysis has been performed to examine the relationship between corporate governance and firms' financial performance. The dependent variables are company performance (measured by Tobin's Q, ROA and ROE). The independent variables are board size, CEO Duality, board independence, board meeting frequency, audit committee size, audit committee independence, promoter shareholding and institutional shareholding. Control variables include the firm size and capital gearing ratio. To find out the impact of corporate governance measures on firm performance, following model is created:

$$
\begin{array}{r}
\text { Tobin's } \mathrm{Q}=\alpha+\beta 1(\mathrm{BODSIZE})+\beta 2(\mathrm{CEODUAL})+\beta 3(\mathrm{BIND})+\beta 4(\mathrm{BMEET})+\beta 5(\mathrm{ADSIZE})+\beta 6(\mathrm{ADIND})+\beta 7 \\
(\mathrm{PHOLD})+\beta 8(\mathrm{IHOLD})+\beta 9(\mathrm{SIZE})+\beta 10(\mathrm{CGEAR})+\varepsilon \ldots . . \\
\mathrm{ROA}=\alpha+\beta 1(\mathrm{BODSIZE})+\beta 2(\mathrm{CEODUAL})+\beta 3(\mathrm{BIND})+\beta 4(\mathrm{BMEET})+\beta 5(\mathrm{ADSIZE})+\beta 6(\mathrm{ADIND})+\beta 7(\mathrm{PHOLD})+ \\
\beta 8(\mathrm{IHOLD})+\beta 9(\mathrm{SIZE})+\beta 10(\mathrm{CGEAR})+\varepsilon \ldots . . \\
\mathrm{ROE}=\alpha+\beta 1(\mathrm{BODSIZE})+\beta 2(\mathrm{CEODUAL})+\beta 3(\mathrm{BIND})+\beta 4(\mathrm{BMEET})+\beta 5(\mathrm{ADSIZE})+\beta 6(\mathrm{ADIND})+\beta 7(\mathrm{PHOLD})+\beta 8 \\
(\mathrm{IHOLD})+\beta 9(\mathrm{SIZE})+\beta 10(\mathrm{CGEAR})+\varepsilon \ldots . .
\end{array}
$$


Table 1. Variable Definition.

\begin{tabular}{lll}
\hline Variable Name & Symbol & Measurement \\
\hline Board Size & BODSIZE & The total number of directors on the board \\
CEO Duality & CEODUAL & When CEO is also the board chair, it is defined 1, or else 0. \\
Board Independence & BIND & Proportion of Independent directors to total board size \\
Board meeting frequency & BMEET & Number of times of meeting during the financial year \\
Size of audit committee & ADSIZE & Number of members of the audit committee \\
Audit committee independence & ADIND & Dummy variable if the IDs on the Audit committee is more than $50 \%$ is 1 , otherwise 0 \\
Promoters shareholding & PHOLD & Percentage of equity shares held by Promoters \\
Institutional Shareholding & IHOLD & The percentage of equity shares held by Institutions \\
Size of firm & SIZE & Natural logarithm of Book value of total assets of the firm \\
Capital Gearing Ratio & CGEAR & It is computed by dividing the common stockholders' equity by fixed interest or dividend bearing funds. \\
\hline
\end{tabular}

\section{Results and Discussions}

\subsection{Descriptive Statistics}

Table 2 shows the minimum boards are three with a maximum board size of twenty and on an average size are 8.87 on each firm's board of directors. Results indicated the majority of the firms have 8-10 directors on the board. This suggests that sample firms having their medium sized boards. Concentrating on the CEO chair of the board, only 45.9 percent firms have person with the dual function of president and CEO. In India, managing director and CEO terms are used interchangeably. The consequences of the role separation between the chairperson and CEO suggest that virtually half the number of firms is voluntarily complying with the suggestions for best practices are recommended by several corporate governance codes nationally and internationally.

On board independence the study indicates that minimum board independence is 0.00 on an average firms have 32 percent and maximum is 66.67 and on an average firms have about 47.065 independent directors on their control panels which are closely consistent with the corporate governance guidelines. The revised clause 49 states that a company is required to have an optimum combination of inside and outside directors where the chairman is the insider. The necessity for outside directors on the board us reduced 30 percent where the president in an outsider. Literature also suggested the higher the proposition of outside directors associated with stronger financial performance. In terms of board activity, the sample firms hold four to twenty meetings in the financial year, with a mean and standard deviation of 5.924 and 2.287 respectively. The size of the audit committee has minimum is two and a maximum of nine members with an average of 3.836 which is consistent to fulfil the norms of the corporate governance regulations. The audit committee independence is the minimum of 12.5 and maximum is 100 percent and on average firms have about 88.82 percent on their audit committee which are consistent with the corporate governance guideline laid down in India. The promoter shareholding is an average of 54.243 percent, which implies that majority of the firm's shareholding in the workforce of the boosters of the manufacturing firms in India. The institutional shareholding concern with an average of 8.589 percent only, but the range of shareholding between 0 and 97.64.

Table 2. Descriptive Statistics.

\begin{tabular}{|c|c|c|c|c|c|}
\hline & $\mathbf{N}$ & Mean & Std. Deviation & Minimum & Maximum \\
\hline BODSIZE & 3570 & 8.872 & 2.838 & 3.000 & 20.000 \\
\hline CEODUAL & 3570 & 0.459 & 0.498 & 0.000 & 1.000 \\
\hline BIND & 3570 & 47.065 & 14.052 & 32.000 & 66.667 \\
\hline BMEET & 3570 & 5.924 & 2.287 & 4.000 & 20.000 \\
\hline ADSIZE & 3570 & 3.836 & 0.980 & 2.000 & 9.000 \\
\hline ADIND & 3570 & 88.826 & 16.554 & 12.500 & 100.000 \\
\hline PHOLD & 3570 & 54.243 & 18.130 & 0.000 & 97.640 \\
\hline SIZE & 3570 & 3.206 & 0.782 & 0.950 & 5.706 \\
\hline CGEAR & 3570 & 16.869 & 30.804 & -100.000 & 339.480 \\
\hline BODSIZE & 3570 & 3.526 & 4.199 & 0.101 & 26.825 \\
\hline CEODUAL & 3570 & 0.064 & 0.198 & -0.653 & 2.365 \\
\hline BIND & 3570 & 0.129 & 0.703 & -10.994 & 5.990 \\
\hline
\end{tabular}

The descriptive results also indicate that the firms average size of is 3.206 and ranges between 0.950 and 5.706 which implies the sample companies have in the categories of small, medium and large sized in their samples. The capital gearing ratio of the firms with an average of 16.869 times and ranges between -100 and 339.48 times. The firm's performance variables the shows wide variations in their Tobin's Q (minimum 0.101 and maximum 26.825 with an average of 3.526). In terms of ROA (minimum -0.653 and maximum 2.365 with an average of 0.064 and ROE (minimum -10.994 and maximum 5.990 with an average 0.129 ). 


\subsection{Correlation Analysis}

Table 3. Correlation Coefficient Among various Corporate Governance, Firm Characteristics and Firm Performance.

\begin{tabular}{llllllllll}
\hline & \multicolumn{2}{l}{ Model 1: Tobin's Q } & \multicolumn{3}{l}{ Model 2: ROA } & \multicolumn{3}{l}{ Model 3: ROE } \\
\cline { 2 - 9 } & Coeff. & p-value & Sig. & Coeff. & p-value & Sig. & Coeff. & p-value & Sig. \\
\hline BODSIZE & 0.067 & 0.003 & $* * *$ & 0.005 & 0.414 & NS & 0.001 & 0.492 & NS \\
CEODUAL & -0.015 & 0.267 & NS & -0.037 & 0.064 & $*$ & -0.035 & 0.073 & $*$ \\
BIND & 0.062 & 0.005 & $* * *$ & -0.010 & 0.338 & NS & -0.005 & 0.421 & NS \\
BMEET & 0.045 & 0.031 & $* *$ & 0.034 & 0.080 & $*$ & 0.020 & 0.203 & NS \\
ADSIZE & 0.009 & 0.356 & NS & 0.094 & 0.000 & $* * *$ & 0.032 & 0.096 & $*$ \\
ADIND & 0.038 & 0.058 & $*$ & -0.061 & 0.006 & $* * *$ & -0.069 & 0.002 & $* * *$ \\
PHOLD & 0.243 & 0.000 & $* * *$ & -0.369 & 0.000 & $* * *$ & -0.258 & 0.000 & $* * *$ \\
IHOLD & 0.046 & 0.030 & $* *$ & -0.025 & 0.156 & NS & 0.014 & 0.288 & NS \\
SIZE & -0.820 & 0.000 & $* * *$ & 0.642 & 0.000 & $* * *$ & 0.573 & 0.000 & $* * *$ \\
CGEAR & 0.014 & 0.281 & NS & -0.007 & 0.380 & NS & 0.001 & 0.489 & NS \\
\hline
\end{tabular}

Note: $* * *, * * *$ indicate t-statistic significance at $10 \%, 5 \%$ and $1 \%$ levels, respectively and NS indicates 'Not Significant'.

The Pearson correlations presented in Table 3 generally suggest that audit committee independence, promoter shareholding and firm size have a significant relationship with all the performance measures.

Table 3 depicts the Pearson's correlation of all variables at the level of significance. The board size is positively correlated with Tobin's Q at the 0.01 level of significance but not significant with ROA and ROE. CEO duality is negative and significant relationship with ROA and ROE at 10\% level of significance but not significant with Tobin's Q. Board independence is positive and significant at 0.05 level in case of Tobin's Q whereas negative and insignificant results were found in ROA and ROE. Board meeting frequency is positive relationship with Tobin's Q \& ROA and result are statistically significant at 0.05 and 0.10 level of significance respectively. Size of audit committee is positive and insignificant result with Tobin's Q whereas the correlation result is significant with ROA at $1 \%$ level and ROE at $10 \%$ level. Audit committee independence is positively correlated with Tobin's Q with 0.10 level and the other cases were negative and significant at ROA \& ROE at 0.01 level of significance. The promoter's shareholding is significantly negatively related to the performance measures of ROA and ROE and positive in case of Tobin's $Q$ but the results were significant at 0.01 level of significance. Institutional shareholding is positive and significant relationship with Tobin's Q and other cases were found to be statistically insignificant. Size of the firm is significantly negatively correlated with Tobin's Q and positively associated in case of ROA and ROE while the results were statistically significant at 0.01 level of significance. The capital gearing ratio is negative and significantly correlated with ROA and others are positive relationship were found but all the cases insignificant to the firm performance.

\subsection{Diagnostics for Regression Analysis}

Regression models may encounter any or the combinations of several problems, e.g. wrong coefficient estimates and wrong standard errors, etc. In order to achieve more reliable and consistent estimates, our regression model demands to possess some desirable properties, which should be in line with OLS five assumptions. Hence various regression diagnostic tests are necessary before running a regression model. Each diagnostic test and the corresponding findings will be discussed below, starting from the five assumptions, then multicollinearity and stationarity.

\section{Assumption 1: $E\left(\mu_{t}\right)=0$}

The first assumption requires the fair value of the mistakes to be zero, [50] claims that as far as a regression equation include a constant condition, this presumption will not be offended.

Assumption 2: $\operatorname{var}\left(\mu_{t}\right)=\sigma 2<\propto$

The second premise is that the divergence of the errors is constant; this is also called the assumption of homoscedasticity. Otherwise heteroskedasticity would exist, supposing that the residuals are changing systematically with explanatory variables. Heteroscedasticity is often recognized in the cross-sectional data. If the errors are heteroscedastic, OLS estimators no longer best linear unbiased estimators. In other words, they no longer hold the minimal variance [50]. Two simple tests for heteroskedasticity are Breusch-Pagan Godfrey (BPG) test and White's test. The null hypothesis for BPG test is that errors are homoscedastic.

Test of Heteroskedasticity - Breusch-Pagan-Godfrey test

The Breusch-Pagan-Godfrey Test (Breusch-Pagan test) is a test for Heteroskedasticity of errors in regression. The Breusch-Pagan (BP) test is one of the most common tests for Heteroskedasticity. It begins by allowing the heteroskedasticity process to be a function of one or more of the independent variables, and it's usually applied by assuming that heteroskedasticity may be a linear function of all the independent variables in the model. Heteroscedasticity means "differently scattered"; this is opposite to homoscedastic, which means "same scatter." Heteroscedasticity tests imply the two following hypotheses.

Null Hypothesis $\mathrm{H}_{0}$ : data are homoscedastic.

Alternative hypothesis Ha: data are heteroscedastic. 
Table 4. Test for Heteroskedasticity.

\begin{tabular}{llllllll}
\hline \multirow{2}{*}{ SI.No } & \multirow{2}{*}{ Dependent Variable } & \multicolumn{2}{l}{$\begin{array}{l}\text { Breusch Pagan-Godfrey } \\
\text { Ho: data are homoscedastic. }\end{array}$} & \multicolumn{2}{l}{$\begin{array}{l}\text { White Test } \\
\text { Ho: heteroskedasticity not present }\end{array}$} & \multicolumn{2}{l}{$\begin{array}{l}\text { Wald Test Ho: the units have a } \\
\text { common error variance }\end{array}$} \\
\cline { 3 - 8 } & & F-statistic & P value & LM test & P value & Chi-square & P value \\
\hline 1 & Tobin's Q & 22.971 & 0.0000 & 1238.59 & 0.0000 & 10.854 & 0.0543 \\
2 & ROA & 19.556 & 0.0000 & 917.09 & 0.0000 & 10.716 & 0.0574 \\
3 & ROE & 13.225 & 0.0022 & 385.772 & 0.0000 & 14.329 & 0.0722 \\
\hline
\end{tabular}

Therefore, if the p-value associated to a heteroskedasticity test falls below a certain threshold ( $p$ value $<0.05$ ). The result would conclude that the data is significantly heteroscedastic. The result shows that $\mathrm{F}$ - statistic is significant, meaning that the null hypothesis should be rejected, thus heteroskedasticity exist in the test variables. The results proved that data is heteroskedasticity. In addition that the p-value for both tests is by far below the significance level of 0.05 . Hence, reject the null hypothesis that the residuals are heteroskedasticity.

Further, the Wald test (also called the Wald Chi-Squared Test) is a way to find out if explanatory variables in a model are significant. "Significant" means that they add something to the model; variables that add nothing can be deleted without affecting the model in any meaningful way. The test can be employed for a large number of different models including those with binary variables or continuous variables. If the Wald test shows that the parameters for certain explanatory variables are zero, you can remove the variables from the model. From the table 4, the test shows the parameter $\mathrm{p}$ values are not zero, therefore, the variables should include in the model.

\section{Assumption 3: $\operatorname{cov}\left(\mu_{i}, \mu_{j}\right)=0$ for $i \neq j$}

It assumes that the covariance between the error terms over time or cross-section is zero, meaning that the errors are uncorrelated with one another. If the autocorrelation exists, the coefficient estimates derived from OLS are inefficient and R-squared gets inflated to its "correct value" for positive autocorrelation. Durbin- Watson (DW) test is used to test for first order autocorrelation with the null hypothesis that the error terms are independent of one another [50]. The Durbin Watson Test is a measure of autocorrelation (also called serial correlation) in residuals from the regression analysis. Autocorrelation is the similarity of a time series over successive time intervals. It can lead to underestimates of the standard error and can cause that to think predictors are significant when they are not. The Hypotheses for the Durbin
Watson test are:

$\mathrm{H}_{0}=$ no first order autocorrelation.

$\mathrm{H}_{1}=$ first order correlation exists.

Table 5. Test for Autocorrelation - Durbin-Watson Test.

\begin{tabular}{llll}
\hline Sl.No & Dependent Variable & D-W Statistics & P value \\
\hline 1 & Tobin's Q & 1.98133 & 0.38387 \\
2 & ROA & 1.9925 & 0.47441 \\
3 & ROE & 1.9445 & 0.2557 \\
\hline
\end{tabular}

The Durbin Watson test reports a test statistic, with a value from 0 to 4 , where, the value is exactly 2 which implies has no autocorrelation. The value between 0 to less than 2 is positive autocorrelation (common in time series data). Similarly, the value between greater than 2 to 4 is negative autocorrelation (less common in time series data).

Consequently, the DW test indicates no autocorrelation exists since the consequences of the DW value closes in 2 . Table 5 results proved that the DW test $p$ value is not significant and accept the null hypothesis which implied that there is no first order autocorrelation.

Assumption 4: the xt are non-stochastic

It indicates that the independent variables are nonstochastic, implying that the repressors are not correlated with the error term of the estimated equation, otherwise OLS estimator will be biased and inconsistent. Hausman test is used to examine heterogeneity. The test is called forth to obtain the preferred model from the two panel models. The effects of the Hausman test are presented in Table 6. The Hausman test rejects the random effect model against the fixed effect model for ROA and ROE. However, the null hypothesis of the Hausman test is accepted for the Tobin's Q. Therefore, both the panel data regression models have been used, that is, the fixed effect model for ROA \& ROE and the random effect model for the Tobin's Q.

Table 6. Hausman Test (Test for Heterogeneity).

\begin{tabular}{llllll}
\hline $\begin{array}{l}\text { Model with dependent } \\
\text { variable }\end{array}$ & $\begin{array}{l}\text { Chi-Square } \\
\text { Statistics }\end{array}$ & $\begin{array}{l}\text { Degree of } \\
\text { freedom }\end{array}$ & p-value & Result & Remarks \\
\hline Tobin's Q & 7.354 & 10 & 0.692 & Not Significant & Random effect model is appropriate \\
ROA & 47.340 & 10 & 0.000 & Significant at 0.01 level & Fixed effect model is appropriate \\
ROE & 80.343 & 10 & 0.000 & Significant at 0.01 level & Random effect model is appropriate \\
\hline
\end{tabular}

\section{Assumption 5: (ut N $(0, \sigma 2)$}

The last assumption implies that the disturbances are normally distributed. One of the most commonly used method is to observe the histogram plot of the residuals to see if the residuals are normally distributed. The most common statistical tests rely on the normality of a sample or population, it is frequently useful to try whether the underlying distribution is normal, or at least symmetric. The p-value is significant which indicates that the null hypothesis of normality should be rejected. Even so, with a large sample 
like in our instance, non-normality is not seen as a problem. By observing the histogram plot of the residuals, our residuals are close to being normally distributed.

Null hypothesis $\mathrm{H}_{0}$ : Data follow a normal distribution

Alternative hypothesis $\mathrm{H}_{1}$ : Data do not pursue a normal distribution

Table 7. Test for normality of residual (Jarque Berra Test).

\begin{tabular}{llll}
\hline $\begin{array}{l}\text { Dependent } \\
\text { Variable }\end{array}$ & Test statistic & Test Value & P value \\
\hline Tobin's Q & Chi-square(2) & 1832.670 & 0.0000 \\
ROA & Chi-square(2) & 34796.286 & 0.0000 \\
ROE & Chi-square(2) & 2560.878 & 0.0000 \\
\hline
\end{tabular}

The results are significant, the errors is not normally distributed. In these results, the null hypothesis states that the data follow a normal distribution. Because the p-value is $0.000(\mathrm{p}<0.001)$, which is less than the significance level of 0.05 , the decision is to reject the null hypothesis. Hence, it is conclude that the data do not follow a normal distribution.

\section{Test for Multicollinearity}

Multicollinearity is a state of very high inter-correlations or inter-associations between the independent variables. It is therefore a type of disturbance in the data, and if present in the data the statistical inferences made about the data may not be reliable. Multicollinearity can also be detected with the help of tolerance and its reciprocal, called variance inflation factor (VIF). If the value of tolerance is less than 0.2 or 0.1 and, simultaneously, the value of VIF 10 and above, then the multicollinearity is problematic. The results reveal no multicollinearity among variables as no absolute correlation value exceeds 1.367 . With the threshold of the Variance Inflation Factors Minimum possible value $=1.0$ and Values $>10.0$ may indicate a collinearity problem.

Table 8. Variance Inflation Factor.

\begin{tabular}{lll}
\hline \multirow{2}{*}{ Variable } & \multicolumn{2}{l}{ Collinearity Statistics } \\
\cline { 2 - 3 } & VIF & Tolerance \\
\hline BODSIZE & 1.346 & 0.743 \\
CEODUAL & 1.090 & 0.918 \\
BIND & 1.033 & 0.968 \\
BMEET & 1.013 & 0.987 \\
ADSIZE & 1.293 & 0.774 \\
ADIND & 1.074 & 0.931 \\
PHOLD & 1.367 & 0.731 \\
IHOLD & 1.254 & 0.797 \\
SIZE & 1.227 & 0.815 \\
CGEAR & 1.015 & 0.985 \\
\hline
\end{tabular}

Test for Unit roots or stationarity - Levin, Lin and Chu model

After checking the absence of multicollinearity and before applying the panel data regression, stationary of all the variables being studies was checked using a unit root test. A stationary series can be defined as one with a constant mean, constant variance and constant auto co-variances for each given lag. The use of non-stationary data can lead to spurious regression (Brooks, 2008). The unit root test was used to check whether a series is stationary or not. The unit root test is based on testing the null hypothesis that series is not stationary [51]. The results of the unit root test are presented here in table 8 as follows.

$\mathrm{H}_{0}$ : Panels contain unit roots

Ha: Panels are stationary

Table 9. Panel Unit Root Test Summary.

\begin{tabular}{llllll}
\hline Method & $\begin{array}{l}\text { Z } \\
\text { Statistic }\end{array}$ & Prob.** & Lags & $\begin{array}{l}\text { Cross- } \\
\text { sections }\end{array}$ & Obs \\
\hline Tobin's Q & -46.1680 & 0.0000 & 22 & 357 & 3565 \\
ROA & -47.5923 & 0.0000 & 22 & 357 & 3565 \\
ROE & -46.8114 & 0.0000 & 22 & 357 & 3565 \\
BODSIZE & -47.3806 & 0.0000 & 22 & 357 & 3565 \\
CEODUAL & -52.3972 & 0.0000 & 22 & 357 & 3565 \\
BIND & -49.2332 & 0.0000 & 22 & 357 & 3565 \\
BMEET & -54.2833 & 0.0000 & 22 & 357 & 3565 \\
ADSIZE & -55.4864 & 0.0000 & 22 & 357 & 3565 \\
ADIND & -49.4484 & 0.0000 & 22 & 357 & 3565 \\
PHOLD & -49.1881 & 0.0000 & 22 & 357 & 3565 \\
IHOLD & -49.5820 & 0.0000 & 22 & 357 & 3565 \\
SIZE & -48.2054 & 0.0000 & 22 & 357 & 3565 \\
CGEAR & -51.4038 & 0.0000 & 22 & 357 & 3565
\end{tabular}

Note: Levin-Lin-Chu pooled ADF test User-specified lags: 0; Null: Unit Root (assumes a common unit root process)

Table 9 depicted that all the variables are stationary in nature. The $p$ value of these variables is less than 0.05 . LLC's results show that the null hypothesis for all variables should be rejected, thus all our data series are stationary. The null hypothesis is that the series contains a unit root, and the alternative is that the series is stationary. The Levin-Lin-Chu bias-adjusted $Z$ statistic which is significant at all the usual testing levels. Therefore, the result were rejected the null hypothesis and conclude that the series is stationary. This means null hypothesis is rejected and the series is stationary in nature. As the output indicates, the Levin-Lin-Chu test assumes a common autoregressive parameter for all panels.

Test for Causality - Granger Causality Test

Granger causality is a statistical concept of causality that is based on prediction. To investigate the causal relationship between two variables with the help of granger causality test. Although regression analysis deals with the dependence of one variable on other variables, it does not imply causation. In addition to the panel regression, granger causality test is deployed to find out if whether the dividend policy will impact the selected factors backwards. At one extreme are people who believe that "everything causes everything" [52]. To further study the relationship between financial performance and the selected corporate governance factors, granger causality test is applied. Granger causality test is dealing with bilateral causality and it can detect the direction of causality. With the granger causality test, in order to test the financial performance variable with each of the determinant separately. 
Table 10. Granger Causality Test.

\begin{tabular}{lllll}
\hline Null Hypothesis & No. Observation & F-statistics & Probability & Results \\
\hline Tobin's Q does not Granger Cause BODSIZE & 3570 & 3.64645 & 0.0263 & Ho-Accepted \\
Tobin's Q does not Granger Cause CEODUAL & 3570 & 1.7442 & 0.1755 & Ho- Rejected \\
Tobin's Q does not Granger Cause BODIND & 3570 & 0.7990 & 0.4650 & Ho- Rejected \\
Tobin's Q does not Granger Cause BMEET & 3570 & 1.9766 & 0.1389 & Ho- Rejected \\
Tobin's Q does not Granger Cause ADSIZE & 3570 & 1.5723 & 0.2079 & Ho- Rejected \\
Tobin's Q does not Granger Cause ADIND & 3570 & 5.4256 & 0.0045 & Ho-Accepted \\
Tobin's Q does not Granger Cause PHOLD & 3570 & 2.0703 & 0.1265 & Ho- Rejected \\
Tobin's Q does not Granger Cause IHOLD & 3570 & 3.8213 & 0.0329 & Ho-Accepted \\
Tobin's Q does not Granger Cause SIZE & 3570 & 1.65108 & 0.1922 & Ho- Rejected \\
Tobin's Q does not Granger Cause CGEAR & 3570 & 0.8660 & 0.4208 & Ho- Rejected \\
\hline
\end{tabular}

Null hypotheses are being displayed in the above output. The results which lies, If $\mathrm{F} \geq 3.84$ then $\mathrm{H}_{\mathrm{a}}$ (Alternate hypothesis are accepted) whereas the value of $\mathrm{F}$ is $\mathrm{F}<3.84$ then $\mathrm{H}_{0}$ (Null hypothesis are accepted). Hence, this tested results proves that the above cause and effect relationship is unidirectional and not bidirectional.

\subsection{Panel Data Regression Analysis}

In order to investigate the relation between firm performance and the chosen independent variables, by testing the three commonly used models: Pooled regression, Random effects model and fixed effects model. As shown in the Table11, the pooled regression results indicate a low value of R-squared of 0.683 , meaning that $68.3 \%$ of the variations in the financial performance can be explained by the changes of independent variables, while all the selected independent variables, of which CEO duality, board meeting frequency, promoter shareholding, institutional shareholding and size of the firm are significant. All significant variables a high level of significance except board meeting frequency at the $5 \%$ level, the other four variables (CEO duality, promoter shareholding, Institutional shareholding and firm size) are significant at 0.01 level. This spurious result-low R-square value with high significant variables- being out the concern whether this pooled regression is reliable and valid. This inaccurate results can also be explained pooled regression does not deal with heterogeneity and time-specialty, hence the information is lost in the time dimension and crosssection dimension.

\section{Tobins $Q$ as a Measure of the Firm Performance}

The results from the redundant fixed effect test reveals that $\mathrm{p}$ value is significant at $1 \%$, meaning that the null hypothesis should be rejected and pooled regression cannot be employed in our sample. Therefore, the study need to further test whether the fixed effects approach or random effects approach is preferred and can be used. The promoter shareholding and firm size have significant at 0.01 level, moreover; the board independence has significant at 0.05 level. The study cannot reject that dependent variable cannot be explained by the joint control variables as the probability of F-statistics $0.000(<0.05)$ and R-squared shows that 93.7 percentage of variations in financial performance (Tobin's Q) can be explained by control variability. However, the study cannot conclude from the results as fixed effects approach is only valid when the composite error term in uncorrelated with all of the explanatory variables. With heterogeneity, the results can be invalid and this also confirmed by Hausman test that random effects model is appropriate in the analysis. The p-value of cross section random is not significant at 0.05 level, indicating that null hypothesis should be accepted and random effects model is appropriate for this panel data model (Tobin's Q). As a result, Random effects model is more suitable and the results employed as the final model.

Table 11. Corporate Governance and Firm's Market based Performance.

\begin{tabular}{llll}
\hline Variable & Fixed Effects & Random Effects & Pooled OLS \\
\hline Constant & 20.2073 & 19.9095 & 18.9473 \\
& $(28.5483)^{* * *}$ & $(31.8415)^{* * *}$ & $(30.1713)^{* * *}$ \\
Board Size & -0.0291 & -0.0093 & 0.0353 \\
& $-(0.9875)$ & $-(0.3688)$ & $(1.5027)$ \\
CEO Duality & -0.1220 & -0.1732 & -0.3151 \\
& $-(0.6438)$ & $-(1.1382)$ & $-(2.6164)^{* * *}$ \\
Board Independence & 0.0093 & 0.0081 & 0.0042 \\
& $(2.4335)^{* *}$ & $(2.2833)^{* *}$ & $(1.0130)$ \\
Board Meeting Frequency & 0.0318 & 0.0364 & 0.0625 \\
& $(1.6093)$ & $(1.9315)^{*}$ & $(2.4710)^{* *}$ \\
Size of Audit Committee & -0.0026 & 0.0020 & $(0.0369)$ \\
& $-(0.0446)$ & 0.0019 & $(0.2021)$ \\
Audit Committee Independence & 0.0030 & $(0.5215)$ & $(0.0789)$ \\
Promoters Shareholdings & $(0.7160)$ & -0.0256 & -0.0219 \\
Institutional Shareholdings & -0.0273 & $-(6.0178)^{* * *}$ & $-(5.8914)^{* * *}$ \\
\hline
\end{tabular}




\begin{tabular}{llll}
\hline Variable & Fixed Effects & Random Effects & Pooled OLS \\
\hline & $-(0.3068)$ & $-(1.5458)$ & $-(4.0389)^{* * *}$ \\
Size of Firm & -4.8313 & -4.7723 & -4.6082 \\
& $-(50.6839)^{* * *}$ & $-(56.5803)^{* * *}$ & $-(56.5648)^{* * *}$ \\
Capital Gearing Ratio & 0.0013 & 0.0013 & 0.0020 \\
No. of Observations & $(1.3452)$ & $(1.4106)$ & $(1.0465)$ \\
R-Squared & 3400 & 3400 & 3400 \\
Adjusted $\mathrm{R}^{2}$ & 0.950 & 0.678 & 0.683 \\
F-Statistics & 0.937 & 0.675 & 0.681 \\
Prob. $(\mathrm{F}-$ Statistics $)$ & 72.716 & 253.072 & 364.178 \\
D-Watson Statistics & 0.000 & 0.000 & 0.000 \\
Hausman $\mathrm{X}^{2}$ Test & 2.027 & 2.022 & 1.419 \\
d.f & 7.354 & $\mathrm{H}_{0}:$ Random Effect model is appropriate \\
P-Value $\left(\mathrm{X}^{2}\right)$ & 10 & Result: $\mathrm{H}_{0}$ Accepted & \\
Note: $* * *$ Significant at $1 \%$ level; ** Significant at $5 \%$ level and $*$ Significant at $10 \%$ level. Dependent Variable: Tobin's Q
\end{tabular}

Overall the probability of F-statistics of $0.000(<0.05)$ indicates that should not reject the null hypothesis that all coefficient are zero, meaning that dependent variable Tobin's $\mathrm{Q}$ can be explained by at least one control variable. Rsquared $(0.675)$ means that $67.5 \%$ variation in Tobin's $Q$ can be explained by at the independent variables. Breaking down into each independent variable board independence, board meeting frequency, size of the audit committee, audit committee independence and capital gearing ratio are positively related to Tobin's Q, while negatively related to board size, CEO duality, promoter shareholding, institutional shareholding and firm size.

A negative relation is found between board size and financial performance (Tobin's Q) according to the t-statistics $(-0.3688)$ which is not significant. The null hypothesis, board size has no impact on financial performance should be accepted, implying that changes in a firm financial performance cannot be excused by its display panel size. The coefficient of board size (0.093) indicates one percentage increase in board size would cause financial performance (Tobin's Q) to decrease by $0.0093 \%$. A negative relation is found between CEO duality and Tobin's Q. The t-statistics of $(-1.1382)$ argues that CEO duality is not important. Thus, the null hypothesis should be assumed, meaning that CEO duality is not significantly influencing the Tobin's Q. CEO duality has a coefficient of (-0.1732), suggesting that one unit, increasing in CEO duality triggers a 0.1732 unit decrease in financial performance. A positive relation is found between board independence and Tobin's Q. The tstatistics of (2.2833) indicates that board independence is significant at 0.05 level. Therefore, the null hypothesis should be rejected, meaning that board independence is significantly influencing the Tobin's Q. Board Independence has a coefficient of $(0.0081)$, indicating that one unit, increasing in board independence, increase with 0.0081 unit increase in financial performance. A positive relation is found between board meeting frequency and Tobin's Q. The tstatistics of (1.9315) indicates that board independence is significant at 0.10 level. Therefore, the null hypothesis should be rejected, meaning that the board meeting frequency is significantly influencing the Tobin's Q. Board meeting frequency has a coefficient of (0.0364), indicating that one unit, increasing in board meeting frequency increase with 0.0364 unit increase in financial performance of market based performance of Tobin's Q. A positive relation is found between audit committee size and Tobin's Q. The t-statistics of (0.0369) indicates that the size of the audit committee is not significant. Therefore, the null hypothesis should be accepted, meaning that the audit committee size is not significantly influencing the Tobin's Q. Audit committee size has a coefficient of (0.0020), indicating that one unit, increasing with audit committee size increase with 0.0020 unit increase in financial performance. A positive relation is found between audit committee independence and Tobin's Q. The t-statistics of $(0.5215)$ indicates that audit committee independence is not significant. Thus, the null hypothesis should be assumed, meaning that audit committee independence is not significantly influencing the Tobin's Q. Audit Committee independence has a coefficient of (0.0019), indicating that one unit, increasing with audit committee independence, and increase with 0.0020 unit increase in financial performance. A negative relation is found between promoter shareholding and Tobin's Q. The t-statistics of (6.0178) indicates that promoter shareholding is significant at 0.01 level. Therefore, the null hypothesis should be rejected, meaning that promoter shareholding is significantly influencing the Tobin's Q. Promoter shareholding has a coefficient of (-0.0256), indicating that one unit, increasing with promoters shareholding increase with 0.0256 units decrease in financial performance. A negative relation is found between institutional shareholding and Tobin's Q. The t-statistics of (-1.5458) indicates that institutional shareholding is not significant. Thus, the null hypothesis should be assumed, meaning that institutional shareholding is not significantly influencing the Tobin's Q. Promoter shareholding has a coefficient of (-0.0256), indicating that one unit, increasing with promoters shareholding increase with a 0.0256 unit decrease in financial performance.

A negative relation is set up between firm size and Tobin's Q. The t-statistics of $(-56.5803)$ argues that firm size is substantial at 0.01 point. Therefore, the null hypothesis should be rejected, meaning that firm size is significantly influencing the Tobin's Q. Firm size has a coefficient of (4.7723), indicating that one unit, increasing with firm size 
increase with a 4.7723 unit decrease in financial performance. A positive relation is found between capital gearing ratio and Tobin's Q. The t-statistics of (1.4106) indicates that capital gearing ratio is not significant. Therefore, the null hypothesis should be accepted, meaning that capital gearing ratio is not significantly influencing the Tobin's Q. The capital gearing ratio has a coefficient of (1.4106), indicating that one unit, increasing with firm size increase with 1.4106 unit increase in financial performance.

ROA as a Measure of the Firm Performance
The output of the regression estimated using ROA as a measure for the firm's performance is shown in Table 12. With heterogeneity, the consequences can be confirmed by Housman test that fixed effect model is appropriate in the analysis. The p-value of cross section random is significant at 0.05 level, indicating that null hypothesis should be rejected and fixed effect model is appropriate for this panel data model (ROA). As a result, the fixed effect model is more suitable and the results employed as the final model.

Table 12. Corporate Governance and Firm's Accounting based Performance.

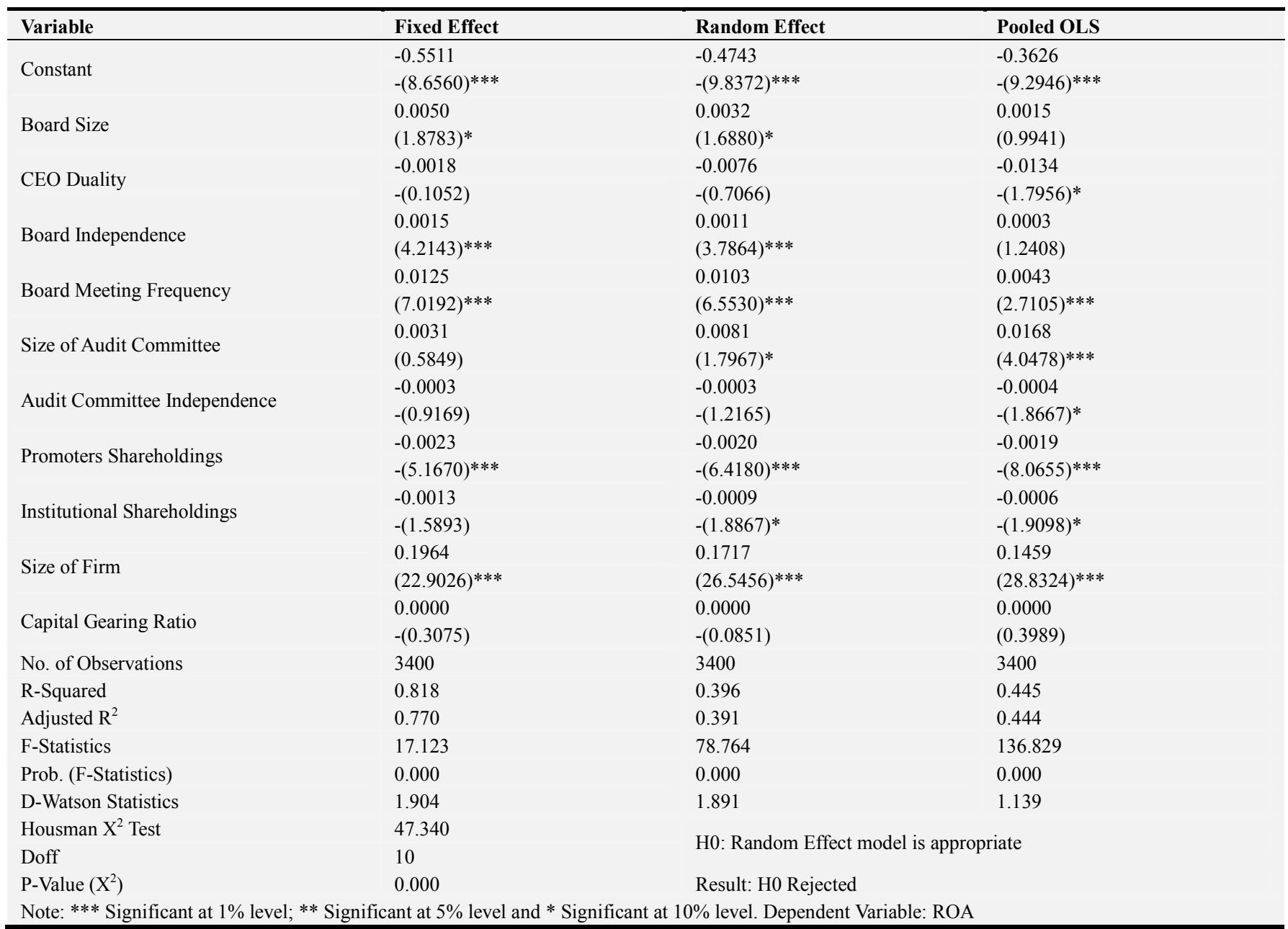

The results of the fixed effect model show positive and significant relationship between board size and firm performance. The result shows that board independence (0.0015), board meeting frequency $(0.00125)$ and firm size (0.1964) were found to be positive and significant relationship with firm performance which are statistically significant at 0.01 level. The promoter shareholding is negative and significant influence on firm performance, which is significant at 0.01 level. The remaining variables such as CEO duality, Size of the audit committee, audit committee independence, institutional shareholding and capital gearing ratio were insignificant results with the firm's performance. The model has a significant explanatory power. The adjusted $\mathrm{R}$ square is approximately 77 percent. The $\mathrm{R}$ square value (0.818) indicates that the dependent variable is explained by all independent variables by 81.8 percent. The f-test is highly significant, thus we can assume that fitted in the model.

ROE as a Measure of the Firm Performance

The resulted output of the regression estimated using ROE as a measure for the firm's performance is shown in Table 13. With heterogeneity, the results can be confirmed by Hausman test that fixed effect model is appropriate in the analysis. The p-value of cross section random is significant at 0.05 level, indicating that null hypothesis should be rejected and fixed effect model is appropriate for this panel data model (ROE). As a result, the fixed effect model is more suitable and the results employed as the final model. 
Table 13. Corporate Governance and Firm's Accounting based Performance.

\begin{tabular}{|c|c|c|c|}
\hline Variable & Fixed Effect & Random Effect & Pooled OLS \\
\hline & -2.5175 & -1.9171 & -1.3641 \\
\hline Constant & $-(9.3888)^{* * *}$ & $-(10.0100)^{* * *}$ & $-(8.9763)^{* * *}$ \\
\hline Board Size & $\begin{array}{l}0.0207 \\
(1.8617)^{*}\end{array}$ & $\begin{array}{l}0.0112 \\
(1.5016)\end{array}$ & $\begin{array}{l}0.0069 \\
(1.2171)\end{array}$ \\
\hline CEO Duality & $\begin{array}{l}0.0493 \\
(0.6877)\end{array}$ & $\begin{array}{l}-0.0164 \\
-(0.3928)\end{array}$ & $\begin{array}{l}-0.0441 \\
-(1.5132)\end{array}$ \\
\hline Board Independence & $\begin{array}{l}0.0012 \\
(0.8365)\end{array}$ & $\begin{array}{l}0.0015 \\
(1.3237)\end{array}$ & $\begin{array}{l}0.0010 \\
(0.9894)\end{array}$ \\
\hline Board Meeting Frequency & $\begin{array}{l}0.0363 \\
(4.8664) * * *\end{array}$ & $\begin{array}{l}0.0287 \\
(4.4434)^{* * *}\end{array}$ & $\begin{array}{l}0.0089 \\
(1.4460)\end{array}$ \\
\hline Size of Audit Committee & $\begin{array}{l}-0.0187 \\
-(0.8314)\end{array}$ & $\begin{array}{l}-0.0047 \\
-(0.2576)\end{array}$ & $\begin{array}{l}0.0096 \\
(0.5944)\end{array}$ \\
\hline Audit Committee Independence & $\begin{array}{l}-0.0027 \\
-(1.7421)^{*}\end{array}$ & $\begin{array}{l}-0.0023 \\
-(2.0305)^{* *}\end{array}$ & $\begin{array}{l}-0.0024 \\
-(2.7123)^{* * *}\end{array}$ \\
\hline Promoters Shareholdings & $\begin{array}{l}-0.0028 \\
-(1.4716)\end{array}$ & $\begin{array}{l}-0.0018 \\
-(1.4286)\end{array}$ & $\begin{array}{l}-0.0016 \\
-(1.7831)^{*}\end{array}$ \\
\hline Institutional Shareholdings & $\begin{array}{l}0.0006 \\
(0.1667)\end{array}$ & $\begin{array}{l}0.0021 \\
(1.1242)\end{array}$ & $\begin{array}{l}0.0024 \\
(1.8533)^{*}\end{array}$ \\
\hline Size of Firm & $\begin{array}{l}0.8319 \\
(23.0593)^{* * *}\end{array}$ & $\begin{array}{l}0.6414 \\
(25.0496)^{* * *}\end{array}$ & $\begin{array}{l}0.5052 \\
(25.6241)^{* * *}\end{array}$ \\
\hline Capital Gearing Ratio & $\begin{array}{l}-0.0002 \\
-(0.4285)\end{array}$ & $\begin{array}{l}0.0000 \\
-(0.1215)\end{array}$ & $\begin{array}{l}0.0002 \\
(0.3462)\end{array}$ \\
\hline No. of Observations & 3400 & 3400 & 3400 \\
\hline R-Squared & 0.744 & 0.318 & 0.339 \\
\hline Adjusted $\mathrm{R}^{2}$ & 0.678 & 0.312 & 0.335 \\
\hline F-Statistics & 11.237 & 56.069 & 136.829 \\
\hline Prob. (F-Statistics) & 0.000 & 0.000 & 0.000 \\
\hline D-Watson Statistics & 1.927 & 1.917 & 1.139 \\
\hline $\begin{array}{l}\text { Hausman } X^{2} \text { Test } \\
\text { d.f }\end{array}$ & $\begin{array}{l}80.343 \\
10\end{array}$ & \multicolumn{2}{|c|}{ H0: Random Effect model is appropriate } \\
\hline P-Value $\left(X^{2}\right)$ & 0.000 & Result: H0 Rejec & \\
\hline
\end{tabular}

The results of the fixed effect model show positive and significant relationship between board size and firm performance, which is statistically significant at 10 per cent level. The result shows that the board meeting frequency $(0.0363)$ and firm size $(0.8319)$ were found to be positive and significant relationship between firm performance which is statistically significant at 0.01 level. The audit committee independence is negative and significant relationship with firm performance, which is significant at 0.10 level. The remaining variables such as CEO duality, board independence, size of the audit committee, promoter shareholding, institutional shareholding and capital gearing ratio were insignificant results with the firm's performance. The model has a significant explanatory power. The adjusted $\mathrm{R}$ square is approximately 67.8 percent. The $\mathrm{R}$ square value (0.744) indicates that the dependent variable is explained by all independent variables by 74.4 percent. The f-test is highly significant, thus we can assume that fitted in the model.

\section{Conclusion}

This study evaluates the impact of board characteristics, board activity, audit committee and ownership structure on corporate financial performance in manufacturing firms in India. Before performing panel regression, a number of diagnostic test need to be conducted in order, check the reliability of our data set. All regressions in this study have been controlled for autocorrelation (DW test), heteroskedasticity (BPG test), heterogeneity (Hausman test), Normality (residual normality histogram), multicollinearity (covariance matrix) and stationarity (Panel root test). Based on the data set is stationary and residuals are not normally distributed and No autocorrelation and multicollinearity exist in the regression model. On the other hand, heteroskedasticity and heterogeneity are spotted in the panel data, but will be taken care of by selection of the final regression model.

Results from the study indicate that there is a positive relation between firm performance and board size, board independence, board meeting frequency and firm size, while a negative relation between firm performance and CEO duality, audit committee size, audit committee independence, promoter shareholding, institutional shareholding and capital gearing ratio. However, CEO duality, audit committee size, institutional shareholding and capital gearing ratio cannot be counted to explain the changes in financial performance because they are tested insignificance. To conclude, financial performance can be significantly and positively explained by the board size, board independence, board meeting frequency and firm size and same results is predicted by [32] [33] [34] [35]. Similarly, financial performance can be significantly and negatively explained by the audit committee 
independence and promoter shareholding and the constituent result with [8]. When looking into how the changes in financial performance may cause changes in each determinant backwards, the Granger causality tests indicate that financial performance not granger cause any of the determinants.

Table 14. Summary of hypothesis testing results.

\begin{tabular}{|c|c|c|c|c|c|}
\hline \multicolumn{2}{|c|}{ Hypothesis } & \multirow{2}{*}{$\begin{array}{l}\text { Tobin's Q } \\
\text { Negative but } \\
\text { Not Significant }\end{array}$} & \multirow{2}{*}{$\begin{array}{l}\text { ROA } \\
\text { Positive and } \\
\text { Significant }\end{array}$} & \multirow{2}{*}{$\begin{array}{l}\text { ROE } \\
\text { Positive and } \\
\text { Significant }\end{array}$} & \multirow{2}{*}{$\begin{array}{l}\begin{array}{l}\text { Overall } \\
\text { Result }\end{array} \\
\text { Positive and } \\
\text { Significant }\end{array}$} \\
\hline H01 & $\begin{array}{l}\text { There is no significant relationship exists between board size and } \\
\text { financial performance of Indian manufacturing firms. }\end{array}$ & & & & \\
\hline H02 & $\begin{array}{l}\text { There is no significant relationship exists between CEO Duality and } \\
\text { financial performance of Indian manufacturing firms. }\end{array}$ & $\begin{array}{l}\text { Negative but } \\
\text { Not Significant }\end{array}$ & $\begin{array}{l}\text { Negative but } \\
\text { Not Significant }\end{array}$ & $\begin{array}{l}\text { Negative but } \\
\text { Not Significant }\end{array}$ & $\begin{array}{l}\text { Negative but } \\
\text { Not significant }\end{array}$ \\
\hline H03 & $\begin{array}{l}\text { There is no significant relationship exists between board independence } \\
\text { and financial performance of Indian manufacturing firms. }\end{array}$ & $\begin{array}{l}\text { Positive and } \\
\text { Significant }\end{array}$ & $\begin{array}{l}\text { Positive and } \\
\text { Significant }\end{array}$ & $\begin{array}{l}\text { Positive but } \\
\text { Not Significant }\end{array}$ & $\begin{array}{l}\text { Positive and } \\
\text { Significant }\end{array}$ \\
\hline H05 & Audit committee size has negative influence on firms performance & $\begin{array}{l}\text { Negative but } \\
\text { Not Significant }\end{array}$ & $\begin{array}{l}\text { Positive but } \\
\text { Not Significant }\end{array}$ & $\begin{array}{l}\text { Negative but } \\
\text { Not Significant }\end{array}$ & $\begin{array}{l}\text { Negative but } \\
\text { Not Significant }\end{array}$ \\
\hline H06 & $\begin{array}{l}\text { Audit committee independence has negative influence on firms } \\
\text { performance }\end{array}$ & $\begin{array}{l}\text { Negative but } \\
\text { Not Significant }\end{array}$ & $\begin{array}{l}\text { Negative but } \\
\text { Not Significant }\end{array}$ & $\begin{array}{l}\text { Negative and } \\
\text { Significant }\end{array}$ & $\begin{array}{l}\text { Negative and } \\
\text { Significant }\end{array}$ \\
\hline H07 & Promoters shareholding has positive influence on firms performance & $\begin{array}{l}\text { Negative and } \\
\text { Significant }\end{array}$ & $\begin{array}{l}\text { Negative but } \\
\text { Not Significant }\end{array}$ & $\begin{array}{l}\text { Negative and } \\
\text { Significant }\end{array}$ & $\begin{array}{l}\text { Negative and } \\
\text { Significant }\end{array}$ \\
\hline H08 & Institutional shareholding has negative influence on firms performance & $\begin{array}{l}\text { Negative but } \\
\text { Not Significant }\end{array}$ & $\begin{array}{l}\text { Negative but } \\
\text { Not Significant }\end{array}$ & $\begin{array}{l}\text { Positive but } \\
\text { Not Significant }\end{array}$ & $\begin{array}{l}\text { - Negative but } \\
\text { Not Significant }\end{array}$ \\
\hline H09 & Firms size has negative influence on firms performance & $\begin{array}{l}\text { Negative and } \\
\text { Significant }\end{array}$ & $\begin{array}{l}\text { Positive and } \\
\text { Significant }\end{array}$ & $\begin{array}{l}\text { Positive and } \\
\text { Significant }\end{array}$ & $\begin{array}{l}\text { Positive and } \\
\text { Significant }\end{array}$ \\
\hline H10 & Capital gearing ratio has negative influence on firms performance & $\begin{array}{l}\text { Positive but } \\
\text { Not Significant }\end{array}$ & $\begin{array}{l}\text { Negative but } \\
\text { Not Significant }\end{array}$ & $\begin{array}{l}\text { Negative but } \\
\text { Not Significant }\end{array}$ & $\begin{array}{l}\text { Negative but } \\
\text { not Significant }\end{array}$ \\
\hline
\end{tabular}

\section{Limitations and Future Research Directions}

As with all empirical studies, the current research has several limitations, and overcoming this can be a guide for future research. First, the data are based on board characteristics; therefore, the research is exempt from the board composition that is the presence of a woman director on the board, board meeting attendance of especially by independent director's concern, Annual General Meeting and a number of meetings conducted by the firms with beyond the required statutory level. Future research could combine measures of the presence of women directors, meeting of independent directors and AGM attendance, which includes some effects on the firm's performance. Second, the current research explores the effect of some board elements such as audit committee and other committees on overall firm's performance. Further research could extend the model to include additional dimensions of the audit committee based measures in order to better understand the firm financial performance. Third, the current study does not include all possible board characteristics that are large shareholders dominance of the board, promoter shareholding and institutional shareholding to support their firm's performance. Further research might include the ownership structure on board to improve the firm's operation. Finally, this research is limited to Indian manufacturing firms. Future research should consider different countries, inter-differences with medium and large scale firms and private \& public undertaking firms. There are certain limitations of this study because it focuses on internal governance mechanisms, ignoring external factors which can have a more significant impact on corporate financial performance.

\section{Acknowledgement}

Indian Council of Social Sciences Research (ICSSR), New Delhi, India.

\section{References}

[1] M. A. M. Makki and S. A. Lodhi, "Impact of corporate governance on firm's performance.," Pakistan Journal of Social Sciences, 33 (2), pp. 265-280, 2013.

[2] A. Shleifer and R. W. Vishny, "A survey of corporate governance," The Journal of Finance, vol. LII, no. 2, pp. 737783, 1997.

[3] R. L. Porte, L. Florencio and A. Shleifer, "Government ownership of banks," Journal of Finance,, vol. 57, no. 1, pp. 265-301, 2002.

[4] J. Sarkar, "Board Independence \& Corporate Governance in India: Recent Trends \& Challenges Ahead," The Indian Journal of Industrial Relations, vol. 44, no. 4, pp. 576-592, 2009.

[5] L. Bebchuk and Y. Grinstein, "The Growth of the Executive Pay," Oxford Review of Econmic Policy, vol. 21, no. 2, pp. 283-303, 2005.

[6] M. Lipton and J. Borsch, "A model proposal for improved corporate governance," The Business Lawyer, vol. 48, no. 1, pp. 59-77, 1992.

[7] M. C. Jensen and W. H. Meckling, "Theory of the firm: managerial behavior, agency costs and ownership structure," Journal of Financial Economics, vol. 3, no. 4, pp. 305-360, 1976. 
[8] N. Balasubramanian, "Board composition and structure of top Indian corporations.," Working Paper. IIMB Centre for Corporate Governance and Citizenship, Indian Institute of Management, Bangalore, 2008.

[9] A. K. Garg, "The relationship between board composition and firm performance: A study of Indian companies," Doctoral Dissertation, Indian Institute of Management, Bangalore, 2005.

[10] V. Kathuria and S. Dash, "Board Size and Corporate Financial Performance: An Investigation," Vikalpa, vol. 24, no. 3, pp. 11-17, 1999.

[11] G. C. Kiel and G. J. Nicholson, "Board Composition and Corporate Performance: How the Australian Experience Informs Contrasting Theories of Corporate Governance," Corporate Governance: an International Review, vol. 11, no. 3, pp. 189-205, 2003.

[12] H. Bathula, "Board Characteristics and Firm Performance: Evidence from New Zealand," Doctoral Dissertation, Auckland University of Technology,, New Zealand, 2008.

[13] A. U. Sanda, T. Garba and A. Mikailu, "Board Independency and Firm Financial Performance," in Economic Development in Africa, University of Oxford., England, 2005.

[14] Jackling, Beverley and J. Shireenjit, "Board Structure and Firm Performance: Evidence from India's Top Companies," Corporate Governance: An International Review, vol. 17, no. 4, pp. 429-509, 2009.

[15] S. Ghosh, "Do Characteristics affect Corporate Performance? Firm level Evidence for India, 13 (7), 435-443.," Applied Economics Letters, vol. 13, no. 7, pp. 453-443, 2006.

[16] A. K. Garg, "Influence of Board Size and Independence on Firm Performance: A Study of Indian Companies," Vikalpa, vol. 32, no. 3, pp. 39-60, 2007.

[17] P. E. Juras and Y. L. Hinson, "Examining the effect of Board Characteristics on Agency Costs and Selected Performance Measures in Banks," Academy of Banking Studies Journal, vol. 7, no. 2, pp. 87-107, 2008.

[18] V. O. Connell and N. Cramer, "The Relationship between Firm Performance and Board Characteristics in Ireland.," European Management Journal, vol. 28, no. 1, p. 387-399, 2010.

[19] T. J. Connelly and P. Limpaphayom, "Board Characteristics and Firm Performance: Evidence from the Life Insurance Industry in Thailand," Chulalongkorn Journal of Economics, vol. 16, no. 2, pp. 101-124, 2004.

[20] S. Ma and G. Tian, "Board Composition, Board activity and Ownership Concentration: The impact on Firm Performance," in Asian Finance Association, University of Queensl and Business School, Brisbane, 2009.

[21] N. Balasubramanian and R. George, "Corporate governance and the Indian institutional context: Emerging mechanisms and challenges in conversation with K. V. Kamath, Chairman, Infosys and ICICI Bank," IIMB Management Review, vol. 24, no. 1, pp. 215-233, 2012.

[22] O. M. Uadiale, "The Impact of Board Structure on Corporate Financial Performance in Nigeria," International Journal of Business and Management, vol. 5, no. 10, pp. 155-166, 2010.
[23] S. Bhagat, J. Brickley and J. Coles, "Managerial indemnification and liability insurance: The effect of shareholder wealth," Journal of Risk and Insurance, vol. 55, no. 1, pp. 721-736, 1987.

[24] E. Fama, "Agency Problems and the Theory of the Firm," Journal of Political Economy, vol. 88, no. 2, pp. 288-307, 1980.

[25] K. C. Chan and J. Li, "Audit committee and firm value: Evidence on outside top executives as expert-independent directors," Corporate Governance: An International Review, vol. 16, no. 2, pp. 6-31, 2008.

[26] J. Dahya and McConnell, "Board Composition, Corporate Performance, and the Cadbury Committee Recommendation," Working Paper No. 2003-003, Purdue University, West Lafayette, Indiana, 2003.

[27] D. Yermack, "Higher Market Valuation of Companies with Small Boards of Directors," Journal of Financial Economics, vol. 2, no. 1, pp. 185-212, 1996.

[28] A. Agrawal and C. R. Knoeber, "Firm Performance and Mechanisms to Control Agency Problems between Managers and Shareholders," Journal of Financial and Quantitative Analysis, vol. 31, no. 3, pp. 377-397, 1996.

[29] C. Pombo and L. H. Gutiérrez, "Outside Directors, Board Interlocks and Firm performance: Empirical Evidence from Colombian Business Groups" Journal of Economics and Business, vol. 63, pp. 251-277, 2011.

[30] R. Othman, H. Ponirin and 1. (. 1.-1. Erlane K Ghani, "The effect of Board Structure on Shareholders' Wealth in Small Listed Companies in Malaysia.," Management Science and Engineering, vol. 13, no. 4, pp. 1-15, 2009.

[31] C. H. Ponnu and R. M. Karthigeyam, "Board Independence and Corporate Performance: Evidence from Malaysia," African Journal of Business Management, vol. 4, no. 6, pp. 858-868, 2010.

[32] A. Arora and C. Sharma, "Impact of firm performance on board characteristics: Empirical Evidence from India,". IIM Kozhikode Society \& Management Review, vol. 4, no. 1, pp. 53-70, 2015.

[33] G. Palaniappan and P. Rao, "Relationship between corporate governance practices and firms performance of Indian context," International Research Journal of Engineering and Technology, vol. 3, no. 3, pp. 1-5, 2015.

[34] S. Sarpal and F. Singh, "Corporate boards, insider ownership and firm-related characteristics: A study of Indian listed firms," Asia-pacific journal of management research and innovation, vol. 9, no. 1, pp. 261-281, 2013.

[35] G. Palaniappan, "Board Characteristics Relating to firms performance: A Study on Manufacturing Firms in India," Journal of Commerce \& Accounting Research, vol. 6, no. 1, pp. 26-36, 2017.

[36] I. Karamanou and N. Vafeas, "The association between corporate boards, audit committees, and management earnings forecasts: An empirical analysis," Journal of Accounting Research, vol. 43, no. 1, pp. 453-486, 2005.

[37] J. V. Carcello and T. L. Neal, "Audit Committee Composition and Auditor Reporting," The Accounting Review, vol. 10, pp. 453-467, 2000. 
[38] C. F. Mendez and A. Garcia, "The Effect of Ownership Structure and Board Composition on the Audit Committee Meeting Frequency: Spanish Evidence," Corporate Governance: An International Review, vol. 15, pp. 909-922, 2007.

[39] K. Raghunandan and D. V. Rama, "Determinants of Audit Committee Diligence,”. Accounting Horizons, 21 (3), vol. 21, no. 3, pp. 265-279, 2007.

[40] V. Sharma, V. Naiker and B. Lee, "Determinants of Audit Committee Meeting Frequency: Evidence from a Voluntary Governance System," Accounting Horizons, vol. 23, no. 3, pp. 245-263, 2009.

[41] M. D. Saibaba and V. A. Ansari, "A Study of CEO Duality, Audit Committees and Corporate Governance in Companies Listed in BSE 200 Index," The IUP Journal of Corporate Governance, vol. X, no. 3, pp. 44-51, 2011.

[42] B. Al-Najjair, "Determinants of he frequency of Board Meetings: Evidence from Categorical Analysis," Journal of Applied Accounting Research, vol. 13, no. 2, pp. 77-85, 2011.

[43] L. J. Abbott, Y. Park and S. Parker, " The effects of audit committee activity and independence on corporate fraud," Managerial Finance, vol. 26, pp. 55-57, 2000.

[44] A. Loana and M. Mariana, "Study regarding the impact of the audit Committee characteristics on company Performance," Studies in Business and Economics, vol. 2, pp. 1-15, 2014.

[45] M. Bianco and P. Casavola, "Italian Corporate Governance: Effects onFinancial Structure and Firm Performance," European Economic Review, vol. 43, pp. 1057-1069, 1999.
[46] C. M. Daily, "The Relationship between Board Composition and Leadership Structure and Bankruptcy Reorganization Outcomes," Journal of Management, vol. 21, no. 6, pp. 10411056, 1995.

[47] S. J. Nickell, D. Nicolitsas and D. Dryden, "What Makes Firm Perform Well?," European Economic Review, vol. 41, pp. 783796, 1997.

[48] L. Zingales, "The Value of the Voting Right: A Study of the Milan Stock Exchange Experience.," The Review of Financial Studies, vol. 7, pp. 125-148, 1994.

[49] J. Li, K. Lam, G. Quian and Y. Fang, "The Effects of Institutional Ownership on Corporate Governance and Performance: An Empirical Assessment in Hong Kong," Management International Review, vol. 46, no. 3, pp. 259276, 2006.

[50] C. Brooks, Introductory Econometrics for Finance, New York: Cambridge University Press, 2014.

[51] R. Kozhan, Financial Econometrics with E-views, New York: Roman Cohan \& Vents Publishing., 2010.

[52] D. Gujarati, Basic Econometrics, Boston: McGraw Hill, 2004.

[53] C. B. Carter and J. Borsch, "Back to the drawing Board: Designing corporate boards for a complex world.," UK, Harvard Business School Press., 2004, p. 76.

[54] N. Balasubramanian, B. S. Black and V. S. Khanna, "The relation between firm-level corporate governance and market value: a case study of India," Emerging Markets Review, 11, pp. 319-340, 2010. 